Policy Research Working Paper 2367

\section{Gender, Poverty, and Nonfarm Employment in Ghana and Uganda}

Constance Newman

Sudharshan Canagarajab

The World Bank

Development Research Group

Rural Development

and

Human Development Network

Social Protection Team

June 2000
For women in Ghana and

Uganda, nonfarm activities

play an important role in

yielding the lowest -

and the most rapidly

declining - rural poverty

rates. In both countries rural

poverty declined fastest for

female heads of housenold

engaged in nonfarm work

I which tended to be a

secondary activity]. But

patterns vary between the

two countries. 
Policy Research Working Paper 2367

\section{Summary findings}

Newman and Canagarajah provide evidence that women's nonfarm activities help reduce poverty in two economically and culturally different countries, Ghana and Uganda.

In both countries rural poverty rates were lowest and fell most rapidly - for female heads of household engaged in nonfarm activities.

Participation in nonfarm activities increased more rapidly for women, especially married women and female heads of household, than for men.
Women were more likely than men to combine agriculture and nonfarm activities. In Ghana it was nonfarm activities (for which income data are available) that provided the highest average incomes and the highest shares of income.

Bivariate probit analysis of participation shows that in Uganda female heads of household and in Ghana women in general are significantly more likely than men to participate in nonfarm activities and less likely to participate in agriculture.

This paper - a joint product of Rural Development, Development Research Group, and the Social Protection Team, Human Development Network - is part of a larger effort in the Bank to discuss gender, employment, and poverty linkages. Copies of the paper are available free from the World Bank, $1818 \mathrm{H}$ Street NW, Washington, DC 20433. Please contact Melvina Clarke, room G8-118, telephone 202-473-1752, fax 202-522-3252, email address mclarke@worldbank.org. Policy Research Working Papers are also posted on the Web at www.worldbank.org/research/workingpapers. The authors may be contacted at cnewman1@worldbank.org or scanagarajah@worldbank.org. June 2000, (43 pages)

The Policy Research Working Paper Series disseminates the findings of work in progress to encourage the exchange of ideas about development issues. An objective of the series is to get the findings out quickly, even if the presentations are less than fully polished. The papers carry the names of the authors and should be cited accordingly. The findings, interpretations, and conclusions expressed in this paper are entirely those of the authors. They do not necessarily represent the view of the World Bank, its Executive Directors, or the countries they represent. 


\title{
Gender, Poverty, and Nonfarm Employment in Ghana and Uganda
}

\author{
Constance Newman and Sudharshan Canagarajah*
}

"Constance Newman is with Rural Development and Poverty and Human Resources in the Development Economics Research Group (DECRG), World Bank, and Sudharshan Canagarajah is with the Social Protection Team in the Human Development Network (HDNSP), World Bank. The funding for this research came from the Poverty Research Report on Gender and the Poverty Reduction and Social Development Division in the Africa Region. We would like to express our thanks to Simon Appleton for his assistance, Patricia Zambrano and Ruchira Bhattamishra for excellent research assistance, and Andrew Mason for his valuable comments on an earlier version of the paper. 



\title{
Gender, Poverty, and Nonfarm Employment in Ghana and Uganda
}

\author{
Constance Newman and Sudharshan Canagarajah
}

\section{Introduction}

Poverty levels in Sub-Saharan Africa are remarkably high, especially in rural areas. In some countries, the majority of rural residents can be classified as poor. Over the last decade, rural poverty has declined, but it is still twice the rate of urban poverty in many countries. To address rural poverty, policy makers are increasingly looking to the growth potential of the nonfarm sectors of the rural economy. Nonfarm sectors such as petty commerce, wage employment, transportation, and construction, have been linked to lower poverty levels in recent work. This paper corroborates these findings and further explores the importance of nonfarm participation to poverty reduction differences by gender. We find that women are increasingly active in the nonfarm economies of Ghana and Uganda and that this participation is linked to greater reductions in poverty for women than for men. The literature to date has not focused on gender differences, but the differences are significant and they show another important benefit of nonfarm activity.

In this paper, we define "nonfarm" as all the activities that are associated with wage work or self-employment in work that is not in agriculture but located in rural areas. Subsistence agriculture is the dominant activity in SSA countries, so we analyze all activities that are "nonfarm" as a way of examining the extent of diversification in the economy. We focus on Ghana and Uganda, each representing not only different economic and political experiences, but also different cultures. We compare trends in rural poverty by gender and sector; changes in income and labor market participation by 
sector and gender; and the determinants of sector participation using a bivariate probit model of participation. Recent studies by Appleton (1999), Deininger and Okidi (1999), and Abdulai and Delgado (1999) explore different aspects of these same issues for Ghana and Uganda, but none focuses specifically on the gender, non-farm, poverty nexus.

A large body of recent research has demonstrated the importance of the non-farm sector. ${ }^{1}$ The non-farm sector provides employment, household income diversification and security, market linkages for agriculture, and thus, the potential for reducing poverty and inequality. ${ }^{2}$ Most authors have concluded that non-farm activities can be seen as a route out of poverty, and that the impacts of non-farm growth on inequality depend on the type of non-farm activity, land tenure patterns, and physical and human capital requirements in question. The role of non-farm work has been examined from a number of perspectives, but one area in the non-farm literature that has not been examined in much detail is that of the different impacts of non-farm development by gender.

Analysis of the gendered impacts of non-farm activity has been included in general overviews of the non-farm sector. But from the little that has been written, the policy implications can be contradictory. Most scholars conclude that growth in non-farm activities is beneficial to women since women are said to participate more in these activities. $^{3}$ But the opposite was described in a recent paper by Abdulai and Delgado about non-farm participation in Northern Ghana. They write that men are more active than women in non-farm work. Others assert that women's traditional role of processing

\footnotetext{
${ }^{1}$ See Reardon (1997) and Ranis and Stewart (1993) as examples.

${ }^{2}$ See Lanjouw and Lanjouw (1995) for a recent survey of the literature. Also see Lanjouw (1997), van de Walle (1993), Hazell and Haggblade (1993), Adams (1994 1999), Reardon and Taylor (1996), and Leones and Feldman (1998).
} 
agricultural output has been supplanted by more modern processing systems, thus replacing women's work. There are many possibilities, especially since "non-farm" as a sector can represent a wide range of activity types. Women's involvement in the different kinds of non-farm activities is likely to be highly varied across different countries and cultural contexts.

In this paper we find that non-farm activities are very important to women's welfare in the two countries of Ghana and Uganda. In both countries, poverty among female headed-households was significantly lower and fell more rapidly over time in those households participating in non-farm activities. In order to get a better idea of the gender dynamics, we explore the implications of these findings by looking at individual level changes in labor market participation and at changes in income by source at the individual level for Ghana. Individual-level income data is not available for Uganda, so we show changes over time in household income. We conclude by discussing our estimates of the determinants of an individual's participation in agriculture and/or non-farm activities rounding out the story of who benefits from non-farm participation and why.

The next section of the paper provides some background on gender roles and the division of responsibilities in the two countries. The third section provides a discussion of the data and methods of approach. The fourth section provides a description of rural poverty trends by gender and sector, and the fifth section describes the trends in sector participation, income, and income shares. The sixth section presents econometric estimates of the joint probability of participation in non-farm and agricultural activities. The final section concludes and recommends areas for further investigation.

${ }^{3}$ Hazell and Haggblade (1993) for Latin America and a World Bank report on the non-farm sector in 


\section{Gender Roles: Division of Labor in Rural Ghana and Uganda}

The division of labor by gender appears to be similar in the two countries with the main difference being that women in Ghana have more access to the market as traders than do women in Uganda. Otherwise, women in both countries work primarily in agriculture with little say in production decisions.

Lloyd and Brandon (1991) review the anthropological literature on the role of Ghanaian women in the division of labor by household. They assert that men have authority over all resources and labor allocation, but that since both men and women have strong ties to extended family, women are able to exercise a fair amount of autonomy within their own economic sphere. Wives usually contribute labor to the family enterprises-which are controlled by their husbands-and engage in their own incomegenerating activities. On the farm, men are usually responsible for the more arduous jobs such as the initial clearing of the land, while women are responsible for the cultivation and processing of crops for home use and market sale. The introduction of cash crops has been linked to increases in inequality between men and women, with men moving more actively toward control of those crops and women taking more responsibility for food crops produced for home consumption.

The roles and responsibilities of men and women are similar in Uganda according to a summary paper by Mugyenyi (1998). Women in Uganda are predominantly occupied in farming, and like in Ghana, they have little access to resources and capital. The men control cash crop farming and revenues, and women provide most of the total labor to food and cash crops. The rights of women in Uganda seem more curtailed however, an 
example being their rights to land ownership. Mugyenyi writes that only 5 percent of land is owned by women as a result of cultural practices that restrict women's inheritance and property ownership. Quoting from a UNICEF study on this subject, she writes:

"There are no statutes that prevent a woman from acquiring property but according to custom, property acquired during marriage belongs to the husband. If a woman leaves her husband, she may have to leave most of her property." (p.137). Mugyenyi describes other women's work in Uganda as being comprised of domestic service and informal sector trade in petty commodities, both of which she says provide very low returns. The overall patterns of division of labor are similar to the ones found in Ghana, but possibly more restricted for women in Uganda.

\section{Data and Methodology}

The analysis in this paper is based on two comprehensive sets of household level data over periods spanning four to five years for each country. The period of analysis for Ghana is from 1987/88 to 1991/92, and though this period does not correspond with the major agricultural reforms, we would expect the rural economy to have benefited from the liberalization of trade and exchange rates that occurred just prior to the period. The period of analysis for Uganda is from 1992 to 1996, corresponding to the implementation of agricultural as well as macroeconomic and trade reforms.

For the Ghana analysis, we use data from the Ghana Living Standards Surveys from 1987/88 and 1991/92 (GLSS1 and GLSS3). These surveys were modeled after the Living Standards Measurement Surveys (LSMS) designed by The World Bank for in-depth poverty measurement. We use the poverty lines and mean per capita expenditure 
variables developed by Coulombe and MacKay (1995) and used by other analysts of these data. The poverty line is defined as 132,300 cedis which amounts to $\$ 25$ per month per person in 1992 prices. The GLSS surveys, which cover about 3000-4000 households, are nationally representative multi-purpose surveys conducted over a period of one year. ${ }^{4}$

For Uganda, we use two household surveys, the Integrated Household Survey from 1992 (IHS 1992) and the fourth Monitoring Survey from 1996 (MS 1996). Like the GLSS, the IHS 1992 survey was modeled after the LSMS to measure welfare. The MS 1996, like the other annual monitoring surveys implemented after 1992, was designed to collect vital welfare data such as consumption and labor data. We use the regional poverty lines and mean per capita expenditure variables developed by Appleton (1999). The resulting weighted average national poverty line is 16443 Ugandan shillings per adult equivalent per month (in 1992 prices) or about $\$ 34$ per person per month.

Since this paper explores the gender dimensions of non-farm activity, we chose to make maximum use of individual level data wherever available. We used all of the information available for economic activity, main and secondary occupations (and tertiary where given), since many people-especially women-participate in more than one sector. In fact, most of the interesting information about non-farm participation comes from the analysis of the different combinations of activities. We also use imputed individual level incomes for Ghana that shed light on the different gender dimensions of the labor market. We estimate individual incomes by combining existing salary data with a proportional share of household income based on the individual's reported participation

\footnotetext{
${ }^{4}$ GLSS1 had a 14 day recall period while GLSS3 had a much smaller 3 day recall period. Since longer recall periods are associated with recall error the expenditure figures had to be corrected using a correction factor of 2.7 for each additional day of longer recall period in order to avoid unwanted bias in the analysis.
} 
and hours worked in the household activity. We conducted the same analysis for Uganda, but the data from the MS 1996 did not permit a reliable comparison.

Income data is known to be of generally poor quality, but we use it here to complement individual level participation data and focus on the relative income differences by gender and sector rather than differences in magnitudes. We make the strong assumption that incomes are distributed according to the amount of time a person spends contributing to the household enterprise. This may not be the case, and thus we would overestimate incomes of the relatively powerless in the household. Despite this bias, we find that the income data tells an important part of the story. As Adams (1999) noted in a recent paper on non-farm earnings in rural Egypt, income data collection efforts should be strengthened if we want to better understand the determinants of growth by sector. We would add that it is especially needed to distinguish gender differences that are usually masked by household income and expenditure totals.

We use household headship as the main indicator of gender differences in this paper, mostly out of necessity, but also because of its qualities as an indicator. We use headship first because the poverty measures are derived from household level consumption data and second because the 1996 Uganda data has minimal information at the individual level. However, the strength of headship as a gender indicator is that it provides the best representation of women's general economic opportunities and circumstances at the household level. Since we have an economy that is composed of households which interact as collective units, rather than one in which individuals interact as purely independent agents, the differences among households as defined by the gender of their head can reveal a lot about different economic experiences. There are, of course, 
many problems with the use of headship that have been highlighted in the literature, so we differentiate by individuals as well wherever data permits.

In the non-farm literature, there are several prevailing approaches to the concept and definition of "non-farm", with no one definition being correct from our point of view. One approach is to identify non-farm by industry, with the result that an individual's occupational status (whether the individual is an employer, employee, or self-employed) is irrelevant to the definition. In that case, for example, one would find all persons employed in agriculture as either wage workers or self-employed farmers grouped together. Further divisions of the dominant agriculture sector may also treat livestock as separate. In this paper, we chose to focus on the occupational aspect and thus isolate the self-employed farmers from the agricultural wage workers, for example. We include livestock and "agricultural services" (very small percentages) with agriculture. For the broad categories that we use in most of the paper, we divide non-farm work into wage work (including agricultural) and all self-employment that is not self-employment in agriculture.

\section{Rural Poverty in Uganda and Ghana}

\subsection{Comparisons of Rural Poverty by Gender}

In both Uganda and Ghana, poverty declined for female-headed households(Tables 1 and 2). However, the results from the two countries differ when the rates of change in poverty for female-headed and male-headed households in the two countries are compared. In Ghana, the rural (and national) poverty rates for male-headed households 
(MHHs) declined at a lower rate than for female-headed households (FHHs) ${ }^{5}$, but in Uganda, the reverse is true. For Ghanaian rural households, FHH poverty decreased by $38 \%$ while that for MHH fell by only $17 \%$. In Uganda, $\mathrm{MHH}$ poverty fell by $20 \%$, and FHH poverty fell by $12 \%$. FHH poverty in Ghana was actually lower than MHH poverty by 1992 . In Uganda, FHH poverty remained slightly higher than MHH poverty, though not significantly. Poverty rates for FHHs and MHHs are very close in Uganda for both years, as also shown for 1992 by Appleton (1996). The results for both countries add to existing evidence that female headship is not in itself a robust indicator of poverty. ${ }^{6}$

\subsection{Rural Poverty by Sector and Gender}

How do rural poverty rates differ by activity? Many people were active in more than one activity, with agriculture being the dominant one, but not always the most important in terms of income. For both countries, almost $90 \%$ were active in agriculture to some extent, but only 60 to $70 \%$ were in agriculture exclusively. Almost a third of the rural population in both countries was active in both agriculture and non-farm activities, and the percentage is even higher for household heads of which $40 \%$ were active in both agriculture and non-farm (Tables 3 and 4).

Table 3 shows poverty statistics with three views on the agriculture/non-farm split: first by main occupation and whether the main occupation is in agriculture or non-farm; second, by whether the person works for any amount of time in agriculture or non-farm as

\footnotetext{
${ }^{5}$ A recent paper by Bhushan and Chao (1997) makes the valid criticism that the poverty statistics by gender reported in the 1995 World Bank report were based on assumptions of equal household size and other assumptions that bias poverty findings downward for female headed households. We recalculated the poverty statistics using their criteria and find that the relative differences in poverty movement over time between male and female headed households are still the same as reported in the 1995 report. Our analysis is available upon request.

${ }^{6}$ Louat et al (1993), Rosenhouse (1989) among others.
} 
either their main or secondary occupation; and third, by whether the person works exclusively in agriculture, exclusively in non-farm, or in both sectors. A clear result from all combinations, for both years, and for both countries, is that non-farm participation corresponds to lower rates of poverty. ${ }^{7}$ The results show the benefits of diversification since individuals in combinations of agriculture and non-farm activities have lower levels of poverty than agriculture only. However, non-farm alone or non-farm as the main occupation shows the lowest levels of poverty overall.

Comparing the rates of change over time between agriculture and non-farm, we find that for both countries, poverty levels for the people in non-farm activities declined more rapidly than for those in agriculture. In Ghana, poverty rates for people working in nonfarm declined only slightly more rapidly than for those working in agriculture. In Uganda, the differences were more pronounced: for those citing agriculture as their main occupation, poverty fell by $20 \%$, and for those in non-farm, it fell by $31 \%$; for those working exclusively in non-farm, poverty fell by the largest amount, $42 \%$; and for those working exclusively in agriculture, poverty fell by only $17 \%$.

Poverty rates fell most rapidly among female heads engaged in non-farm activities in both countries as shown in Table 4. Strikingly in Uganda, the drop in poverty for female heads in non-farm activities was greater than that for male heads despite the much larger overall drop in poverty experienced by all male heads. Poverty reduction for male heads was greater than that for female heads in agriculture as a main job (24 to $17 \%$ ), any agriculture ( 24 to $18 \%$ ), any non-farm ( 31 to $20 \%$ ), agriculture only (18 to $15 \%$ ), and the combination of agriculture and non-farm ( 31 to $23 \%)$. But poverty reduction was greater

\footnotetext{
${ }^{7}$ As other analysts have cautioned, this result cannot tell us whether non-farm activity leads to lower
} 
for female heads than for male heads in the categories of non-farm as a main job (29 to $26 \%$ ) and non-farm alone (44 to $37 \%$ ). In Ghana, less surprisingly, female heads experienced greater reductions in poverty than men in all categories and greater reductions were found for female heads with some connection to non-farm activities. For those female heads in agriculture only, poverty dropped by $31 \%$, and for men it dropped by only $18 \%$. For female heads in non-farm only, poverty fell by $37 \%$ and for men, it fell by $32 \%$. In the combination of agriculture and non-farm, poverty for female heads fell by $35 \%$ also, and for males it fell by only $14 \%$.

\section{Rural Employment and Income Changes in Uganda and Ghana}

To better understand the underlying changes behind poverty reduction in non-farm activities, we examine participation and income data each in a couple of different ways. Since the participation data shows trends at the individual level, we get the clearest picture of what is happening by gender from participation. We first take a snapshot look at the different types of industries comprising non-farm activities and how these differ by gender. We then look in more detail at how participation in the broader categories of agriculture, wage work, and self-employment differ by gender and family role. Then we turn to the income data.

\section{I Sector Participation}

Tables 6 and 7 show industry participation trends for main and secondary activities. Agriculture is clearly the main activity for both genders in both countries, but what is nicely depicted is how important it is to look at secondary activities. Among secondary

poverty, or whether by contrast, the poor face too many barriers to participation in non-farm activities. 
activities, women were more likely to be active in non-farm work than were men, especially by the second period. In 1992 Ghana, only $30 \%$ of women with a secondary activity were in agriculture, compared to $53 \%$ of the men. In 1996 Uganda, $35 \%$ of women and $58 \%$ of the men were in agriculture as a secondary job. However, it is also interesting to note that the number of non-farm industries that women are found in is more circumscribed than it is for men: in both countries, women are clustered into wholesale/retail trade and manufacturing while men's secondary activities are distributed across public administration, trade, several kinds of manufacturing, construction/transport, and forestry/fishing/mining.

The differences in women's roles in the two countries are highlighted in Tables 6 and 7. As described by Mugyenyi, these data show that women in Uganda are primarily farmers, and they are more active than men in agriculture (94 to $80 \%$ ) as a main activity. In Ghana, women have slightly lower participation in agriculture as their main activity compared to men ( 80 to $84 \%$ ), and they have slightly more opportunities than Ugandan women in other sectors. The traditional role of women as market traders in Ghana is clearly shown: in $1988,9 \%$ of Ghanaian women report trade as their main industry and $34 \%$ report it as their secondary industry and by 1992 , these percentages increased to 12 (main) and $41 \%$ (secondary) respectively. The secondary activity participation of Ugandan women shows 7 to $10 \%$ in trade, but much greater concentration in food/beverage manufacturing (18 and 19\% in 1992 and 1996). The main change over time shown in these data raises a very relevant insight to this research. Rural Ugandan women, whose main work is farming, increased their secondary participation in another group of manufacturing industries-textiles, leather, wood, handicrafts-from 4 to $27 \%$. 
This statistic alone reveals the magnitude of these labor market shifts among women and the need to better understand their impacts.

Next we turn to an examination of how the combinations of agriculture and nonfarm activities change over time for different members of the household, with non-farm activities split by wage and self-employment. Tables 8 and 9 show the different combinations of agriculture and non-farm as either main or secondary occupations for Ghana and Uganda. For Ghana, men as a whole were more likely than women to participate exclusively in agriculture: for men the percentage went from $63 \%$ to $70 \%$ while for women it was just over half (54 to $58 \%)$. Almost all of the rest of the women worked in farming plus self-employment (either one as a main occupation for a total of $30 \%$ in 1987 and $27 \%$ in 1991) or in self-employment alone ( $9 \%$ in 1987 and $12 \%$ in 1991). The trends over time for both men and women suggest a movement toward specialization-toward either farming, wage employment or self-employment alone.

In Ghana, the patterns for male and female household heads in Table 8 reveal important differences from the patterns for males and females as a whole. The biggest difference is that a much lower percentage of female household heads worked exclusively in agriculture (from 36 to $42 \%$ ) compared to that for women as a whole (from 54 to $58 \%$ ). Female household heads were more active in the combination of farming and selfemployment (from $40 \%$ in 1987 down to $33 \%$ in 1991). Female heads were more represented in self-employment as a main occupation than women as a whole, up to $18 \%$ in 1991. The participation of male household heads was less concentrated in farming than for males as a group and more equally distributed across the different activity combinations. 
The changing occupations over time of female spouses and females who are neither household heads or spouses ("other female members") rounds out the story of women's patterns in Ghana. Other female members were much more likely than women as a group to be exclusively in farming, and their participation shows a bigger increase over time than any of the other groups shown; participation in farming alone was $62 \%$ in 1987 and increased to $76 \%$ in 1991 . Their participation in all other activities declined over time. Female spouses, on the other hand, had almost the same participation level in farming as women as a whole, except that their participation did not increase as it did for every other group. Female spouses had high and more stable participation in the combination of selfemployment and farming than did women as a whole (32\%). Their participation in selfemployment alone increased from 7 to $11 \%$. Overall the data suggest that the working females with most responsibility for family welfare (spouses and heads) were more active in non-farm activities, especially self-employment. Younger and older female household members increased their participation on the farm.

The story in Uganda is similar to that of Ghana in that the combination of agriculture with self-employment participation increases, especially for women. Table 9 shows that Ugandan women as a whole were more likely than men to participate exclusively in agriculture: $60 \%$ of men in 1991 fell to $54 \%$ and $85 \%$ of women which fell to $67 \%$. The rate for both men and women declined, but more so for women; it fell by 6 percentage points for men and $18 \%$ points for women. Those same women who left working exclusively in agriculture plus a small percentage from wage work must have added self-employment to their agricultural work as participation in self-employment and agriculture increased by $21 \%$. Men also appear to have added self-employment work to 
agriculture, but the switch is not quite as large as for women: $13 \%$ more men combined agriculture and self-employment in 1996.

Ugandan heads of households, both men and women, were much more likely to diversify into other activities than were men and even women as a whole. Over time, female heads show a large drop in farming from 73 to $54 \%$, while male heads' farming participation remained virtually stable at $49 \%$. The participation of both male and female heads in self-employment and farming increases, but it does so much more for female heads: males and females start out at almost the same rate of participation of 16 and $14 \%$ respectively, but females' participation increases to $38 \%$ and males' increases to $28 \%$. Male heads also show a switch from participation in wage work toward self-employment. Overall the trends in female participation in Uganda closely mirror those in Ghana and show a movement toward more non-farm work.

\subsection{Income and Income Shares}

In this section we investigate patterns in reported income by gender and sector (see Tables 10-13). For both countries, there are apparent problems with the comparability of the income figures across the two periods even after adjusting for prices. Therefore, we report only the relative differences for male and female groupings. For Ghana, we use individual level incomes for both periods, but for Uganda, we use household level income data.

For both countries, our data indicate that women earned substantially less than men, though for Ghana the gap may be closing if the relative changes over time for men and women can be compared. For Ghanaian women, the highest average incomes came from 
self-employment, and the most rapid rate of income growth was in self-employment, for both mean and median incomes. For Ghanaian men, the most rapid growth was in either wage employment or self-employment income, depending on whether one uses the mean or median. For both Ghanaian men and women, wage income increased over time, and farm income had the smallest growth over time. Table 10 shows that although Ghanaian men's incomes were higher than women's in all sectors, the percentage gap is smallest for self-employment incomes, particularly when looking at mean incomes. Comparing mean income changes, women earned only $15 \%$ less than men in self-employment, compared to the $33 \%$ and $26 \%$ less they earned in farming and wage employment in 1987 , respectively. By 1991, the percentage gap between men's and women's mean incomes in self-employment had declined to $11 \%$.

The earnings reported for female-headed households in Uganda were significantly lower than those for male-headed households in both years, and if anything, the average earnings grew further apart over time. The difference between average earnings from female-headed households and those from male-headed households went from $33 \%$ to $47 \%$ in 1996. The difference between average earnings in self-employment in the two types of households was highest in both years and grew larger over time, from 46 to $56 \%$. These figures cast heavy doubt on the possibilities for female-headed households in gaining earnings equity via self-employment as the poverty analysis suggests.

Ugandan women —as measured by headship — would seem to have much lower non-farm incomes relative to agricultural incomes compared to Ghanaian women and even compared to Ugandan men. However, we only have earnings data at the household level for Uganda, which is clearly problematic because it hides the earnings of females in 
male-headed households engaged in non-farm activities. From the participation data, we know that by 1996 there was a large increase in female participation in non-farm activities as a secondary activity, especially among female spouses, thereby calling into question the significance of income averages at the household level.

Looking at changes in shares of income provides another perspective. For Ghana, in Table 11, self-employment accounted for a larger percentage of total incomes earned by women $(26 \%)$ than that for men $(9 \%)$ in 1987 . The proportion of self-employment income increased to $31 \%$ for women and $11 \%$ for men. Table 11 also shows how selfemployment income may affect intra-household relations. First, as noted above, women's income share in self-employment income-a high-earning sector-increased, and it decreased in farming, the lowest earning sector. In contrast, men's income shares are almost stable in all three sectors over the period. Compared to women as a whole, married women had the same starting income share from self-employment in 1987 (25\%) but by 1991 had a higher share (34\%) than for women as a whole (31\%). Married women also had a sharper decline in the share of income from farming. In contrast, married men had a smaller increase in the share of self-employment, but their share of farm income remained high and stable at $70 \%$ while their wage income share declined. Married women appear to have gained more than married men, more than men as a group, and slightly more than women as a group.

Examining the trends for the other household members in Ghana, men's income share patterns differed little across the categories with the exception of the "other men" category, men who are neither household heads nor married. Compared to men as a group, these men have much higher and growing income shares from farming, from 86 to 
$91 \%$, and declining shares in the higher-earning sectors. Male household heads and married men are largely overlapping groups and as a result are similar. In contrast to other men, they have higher income shares in the high-earning sectors, with the selfemployment income share increasing and the wage share decreasing.

"Other women" in Ghanaian families who were neither a household head or spouse gained the least among women. Their income share from farming increased, from 75 to $82 \%$, and decreased from 22 to $17 \%$ in self-employment. This, together with the participation data shows that women other than the main income-earners (presumably older and younger women) take over the agriculture duties usually done by the female head or spouse, the higher-earners in the family. Female household heads appear to have gained the most among women; their participation in farming was lowest, and it declined from 56 to $51 \%$. Their self-employment income share was highest and increased from 34 to $43 \%$. And as the only females with significant participation in wage employment, their wage income remained significant, despite a decline from 10 to $6 \%$. On the whole, married women and female heads appear to have gained as a result of increasing income from self-employment. These gains also appear to have been at the expense of more dependent women, young and old, whose income shares moved away from the highearning sectors.

Table 13 shows income share changes for Uganda and Ghana by household head type, male or female. These comparisons for Ghana differ from the above in that they include earnings from the whole household as opposed to above comparisons for household heads only. We see that female headed households gained considerably more in Ghana than they did in Uganda over the periods, with Ugandan female households 
earning an increasing share from agriculture and an only slightly increasing share from self-employment. Male-headed households in Uganda have almost the same distribution of income sources over time, with şlight percent increases from wage and selfemployment. Ghanaian households -both male and female headed-show a significant change in income sources, while Ugandan households' share in agriculture seems to stay fairly fixed and even grow slightly larger for female-headed households.

\section{Understanding the Determinants of Sector Participation in Ghana and Uganda}

In earlier sections we discussed changes in rural poverty and their linkages to farm/non-farm and gender aspects through mostly univariate relationships. In this section, we examine the determinants (individual and household) associated with participation in agriculture and non-farm activities in a multivariate dimension. We use a bivariate probit model to estimate the joint probability of participation in the two sectors. The dependent variable of the first equation takes a value of one if the person participates for any amount of time in agriculture, and the dependent variable for the second equation takes a value of one if the person spends any time in non-farm activities. Since the bivariate probit evaluates how factors influence participation in each sector at the same time, we can see whether the directional impacts are same or opposite for the separate sectors. If a factor is significant in one direction in one of the equations and has the opposite directional impact in the other, our understanding of its impact is strengthened. Alternately, if both equations have factors with the same directional significance, we can conclude that it is an impact not special to that sector alone, but important for participation in general. A bivariate probit models allow for the existence of possible 
correlated disturbances, $\rho$, between two probit equations. It also allows for testing of whether this joint estimation makes a significant difference as opposed to estimating univariate probits for each decision.

Three variations of the base model are estimated for both Ghana and Uganda. The coefficients of the two equations, along with the correlation of the disturbances $\rho$, are jointly estimated using maximum likelihood estimation. (See Annex 1 for a description of the bivariate model.). The slight variations in the model that are presented show some of the independent variables as interactions with gender. Model 1 is the benchmark model in which interaction terms are not included and where a dummy for female household head is included. Model 2 introduces an interaction between the dependency ratio and being female, while Model 3 substitutes the female head dummy (fhh2) for a dummy representing members of a female-headed household (fhh0).

The base model that we estimate includes the same set of independent variables used in recent non-farm participation models (Deininger and Okidi, Lanjouw, Abdulai and Delgado, and others). As in the other studies, and where our data permits, we include regional dummies, age (and age squared), education, distance to markets, non-labor income, land acreage, the ratio of dependents to working adults, and different dummies representing gender. We use dummies for gender differences instead of estimating separate equations by gender in order to directly compare differences by gender rather than differences among men and women. We test for differences in the slopes of the independent variables by gender and for those variables where we find significant differences, we show separate variations of the model which test the separate effects using interaction variables. The estimate of $\rho$ that maximized the bivariate probit 
likelihood function for Ghana was in the range of -0.7 to -0.8 in 1987 and -0.38 in 1992 , while in Uganda it assumed values of -2.6 to -2.7 in 1992 and -1.08 in 1996. All of these were significant at one percent. This negative and significant $\rho$ indicates that on the whole disturbances in the farm/non-farm participation decisions are affected in opposite directions and are not statistically independent. This clearly indicates that parameter estimates obtained from a univariate probit will be inefficient and require a joint estimation as in a bivariate probit. Similarly the likelihood ratio test for joint significance of the independent variables is significant at one percent level. The McFadden $\mathbb{R}^{2}$ shows an indication of goodness of fit of all equations.

\subsection{Ghana}

The results for Ghana are presented in Table 15 for the 1987/88 survey and in Table 16 for the 1991/92 survey. The descriptive statistics for all of the variables used in the estimation are shown in Table 14. For the most part, the estimation results show the factors to have fairly distinguishable effects on participation in one sector or the other. The estimations for the two periods are mostly similar, though there are interesting differences.

Looking at all versions of the models for both years, a clear commonality is that women are significantly less likely than men to be in agriculture and more likely than men to be in non-farm activities. As anticipated, female household heads behave slightly different from women as a whole in that they participate more in agriculture (though not significant in 1992). They also participate significantly more than others in non-farm, as is the case for women on the whole. These effects are found in both years with the 
exception of Model 2 using the 1991/92 data where the "female" dummy in the non-farm equation is not significant (perhaps due to the inclusion of the dependency ratio for females only, discussed below). The participation patterns of members residing in female-headed households is not clear from Model 3; the inclusion of that dummy is insignificant in all but agriculture participation in $1987 / 88$ where they are found to be significantly less likely to participate.

Higher level of education has a negative effect on participation in agriculture, and it has the opposite effect on non-farm participation. This is true of both years, and it is a common finding in the literature (Lanjouw, Deininger and Okidi, and others). The effect of primary schooling is more nuanced: it has a positive but insignificant effect in the agriculture equation in 1987-88 (except for Model 3 where the effect is significant) and a positive and significant effect in the 1987-88 non-farm equation. But by 1992 , primary schooling has a negative and significant impact on agriculture participation, and it has a positive, insignificant impact on non-farm participation in 1991-92. Since the excluded dummy is those with no schooling, this suggests that in 1988 , there was more of a mixture of people with no school and primary school in agriculture, and that by 1992 , those with primary schooling had declined. These patterns indicate that over time some of those with no education have moved toward non-farm, while as a group, those with no schooling became the main group in agriculture.

Distance to markets is an important determinant of growth prospects of the rural economy. Non-farm activities require a certain proximity to trading centers or small towns, while agricultural production gets an added impetus from close proximity to markets. As a proxy for "distance to market" we used a combination of distance traveled 
to school by the children in the family and "distance to work" if the school distance data was not available. The hypothesized negative impact on non-farm participation was significant in the 1992 equation but not in the 1988 equation. Also, the distance variable is negative and significant in the agriculture equation for $1987-88$, indicating that this variable is important for all of rural economy. These results confirm the now perceived wisdom that price incentives alone are not adequate to revise and rejuvenate the rural economy-markets and other infrastructure are necessary.

We expected non-labor income to be an important determinant of non-farm participation as hypothesized by others and since small amounts of capital are probably needed to start self-employment enterprises. Along those lines, some analysts argue that remittances are used to help households start new, non-farm activities. In this estimation, non-labor income is the sum of remittances, rental income, and "other" incomes listed (measured in 100,000 cedis). The results show that non-labor income is a positive and significant determinant of non-farm activity in both periods. The effect of non-labor income on agriculture is positive but not significant for the first two models for the 1987 survey, while it is negative and significant for the 1992 survey. Several explanations could be offered, one being that families with non-labor income moved out of agriculture in the latter period. It could also, by itself, indicate that agriculture families relied less on other sources of income than on the proceeds from agriculture. The first explanation is, however, more in keeping with the evidence on declining agricultural incomes, and the evidence on the growth of importance of non-labor income in non-farm participation in 1991/92. 
As has been the case in many studies of female labor market participation, particularly in developing countries (Behrman and Wolfe, 1984), the dependency ratio was hypothesized to be an important factor in determining non-farm participation. The dependency ratio here is the ratio of the total number of children and non-working adults to the number of working adults in the family. This was thought to be the best relative measure of the family responsibility of each earning individual. The results are not entirely clear. In 1987 , the dependency ratio has a significant impact only on agriculture in Model 1, where the effect is negative. In 1992, however, the effect on agriculture is the opposite (significant and positive). It is also significant and positive for participation in non-farm activities. For 1992, when the interaction dependency ratio "if female" is included, the separate female effect is insignificant for agriculture but positive and significant for non-farm. This interaction term is not significant when using the 1987 data, but at least for 1992, there is some indication that the effect of dependents was more important for females' participation in non-farm work than for males' and that this effect became more important over time.

The regional dummies reveal expected results. The coastal region which is closest to trade routes and urban areas has the most non-farm participation and the least agriculture. The forest region has more, but not significant, agriculture participation than the savanna region which is the excluded dummy. The forest and savanna regions appear to have about the same amount of non-farm activity.

In an attempt to link individual sectoral participation decisions to the differing fortunes of sectors within agriculture, we included household crop acreage. Most families have several crops and not one dominant crop, so we use acreage in each of the 
main categories as the best proxy of the household's diversification strategy as well as the extent of their investment in agriculture. The main crop groups are cocoa, cereals (millet, maize, guinea corn, sorghum, and rice), fruit and vegetables (tomatoes, okra, onions, garden eggplants, eggplants, pineapples, oranges, mangoes, etc.) oils and pulses (ground nuts, palm oil, etc.), and starches (plantains, cocoyams, yams, and sweet potatoes). As a caveat, the data from the two different survey periods differ substantially in magnitude, with the data from 1992 being much smaller. Agriculture is known to have suffered a large depression over this time, but the magnitudes of differences in the data reported seem too large to be correct. The relative acreage totals and patterns would still reveal information about differential sector participation.

In the estimation for $1987-88$, none of the family crop acreages were more likely than the others to lead to agricultural participation. In 1988, there were three crops that did have a negative and significant effect on non-farm participation: fruit \& vegetables, oils \& pulses, and starches. Then in 1992, all of the crops except for cocoa were positive, significant determinants of participation in agriculture. The biggest effect was from fruit $\&$ vegetables, followed in order by cereals and oils \& pulses. The fact that these crops were significant in 1992 and not in 1988 may be a result of the fall in cocoa production and relative specialization in the other crops in 1992. These crops had the opposite impact on the probability of non-farm participation (except for fruit \& vegetables) completing the symmetry. On the contrary, cocoa acreage was negatively associated with agriculture participation and also negatively associated with non-farm participation. Cocoa production declined rapidly over this period, so these negative impacts on 
participation in both sectors are not surprising, given the direct and indirect linkages of the cocoa sector to the rest of the economy.

The crop results can be explained to some extent by the relation of the crops to markets, both export and internal. Cash crops such as cocoa, fruits \& vegetable, starches, and to a lesser extent oils \& pulses had different trajectories over the period and presumably different linkages to the non-farm sector. The results may be interpreted to show that the crops of cereals, oils \& pulses, and starches which did not have strong linkages to the non-farm sector grew in relative importance as determinants of agriculture participation and as an alternative to non-farm work. Cocoa's fall had a negative effect on both sectors, presumably because it had strong linkages to markets. Similarly, fruit and vegetables also having linkages to non-farm markets show positive impact on agriculture and on non-farm though the impacts on non-farm are not significant. These explanations are only to be considered as possible explanations for the results. Much better data is needed to fully understand the changes in the agricultural sector and how they have impacted labor force participation.

\subsection{Uganda}

As with the Ghana data, we estimated bivariate models of participation in agriculture and non-farm employment for Uganda for 1992 and 1996 (Table 17 shows summary statistics and the estimation results are in Tables 18 and 19). We include the same independent variables used in the Ghana base model with the exception of distance to market and agricultural acreage which were not available in the Uganda data. ${ }^{8}$ It is

\footnotetext{
${ }^{8}$ Agricultural acreage is available in the 1995 Monitoring Survey from Uganda, but we chose to use the 1996 survey for the analysis since it is most recent and has more information about labor market participation.
} 
interesting to note that most of the effects we observed in Ghana are also present in Uganda. There are, however, interesting differences.

The main difference from Ghana is that women were more likely than men to be involved in agriculture and this effect was the same for both survey years. However, female household heads were distinguished from women as a group in that they were found to participate significantly less in agriculture in both years. This supports our earlier findings that female heads were moving into non-farm much more than other female household members. For non-farm activities, women were less likely than men to participate but again this effect is mitigated by the opposite, positive and significant effect of being a female head of household on non-farm participation. The results from Model 3 show that like female heads, members of female headed households were significantly less likely to participate in agriculture and significantly more likely to participate in nonfarm activities. This stronger attachment of female heads and their family members to non-farm as opposed to agriculture is only positive to the extent that earnings are higher in non-farm activities. It is possible that female headed households have fewer options and are forced to enter non-farm activities that are less profitable. Since we do not have reliable individual income and hours data for Uganda we cannot fully resolve this question as we have been able to do for Ghana. At least, the poverty analysis suggests that non-farm activities are helping female-headed families out of poverty marginally more so than those in agriculture.

As for Ghana, higher education is an important determinant of participation in nonfarm activities in Uganda. In both years, individuals who pursued primary education and higher education have a higher likelihood of participating in non-farm activities than 
people without any education. The opposite is true for agriculture, though the negative effect of primary education is not significant for agriculture. Having an education level anywhere above primary school, however, makes one much less likely to participate in agriculture. This shows that education is more rewarded in non-farm activities even in rural areas.

Non-labor income, which is defined as it was for Ghana-the sum of income from rent, remittances and other income-is negative and significant for both years in the agriculture equation, but interestingly the effect is also negative for non-farm activities in the 1992 analysis. The effect is not significant in the non-farm equation for the 1996 survey, but it is still negative. This may be interpreted as an indication that neither farming nor non-farm households had access to sufficient "other" income to make a difference to their job participation decision.

The dependency ratio has the expected effect in 1992 when the interaction for gender is included (Model 2), but in 1996, it is insignificant. In 1992, the effect of the dependency ratio when men and women are together leads to higher participation in agriculture and lower participation in non-farm. When you include the interaction with the female dummy, the effect for the interaction term is the opposite. The higher the dependency ratio when the individual is a woman, the more likely she will participate in agriculture and less likely she will participate in agriculture. It is not clear why the same relation would not hold by 1996 .

Living in the Central region has a significant and negative effect on the probability of participating in agriculture and a significantly positive effect on participating in non- 
farm activities. This is consistent with the closer proximity of the Central region to the larger cities, Kampala and Entebbe. The Eastern region show a positive and significant effect on participation in agriculture, while the effect changes from positive to negative for participation in non-farm activities. Finally, the Western region had a negative impact on both agriculture (but insignificant) and non-farm (significant) which is possibly explained by the greater degree of proximity to conflicts in neighboring Rwanda and the Republic of the Congo.

\section{Conclusions}

This analysis has shown that non-farm activities play an important role for women in rural Ghana and Uganda in many ways, but perhaps most importantly, in yielding the lowest as well as the most rapidly declining poverty rates. Non-farm participation led to the largest declines in female poverty rates in both countries despite differences in the gender divisions of labor. Poverty among Ugandan female-headed households declined, but at a slower pace than the poverty rate for male-headed households from 1992 to 1996. The reverse is true for Ghana. Female-headed poverty declined at a faster rate than that for male-headed poverty from 1988 to 1992 . Regardless, both countries showed greater poverty reductions for female-headed households in non-farm work.

Poverty rates for female-headed households in non-farm activities are lower not because they are female-headed households, but because they are in non-farm activities. Non-farm activities were linked to lower and more rapidly falling poverty rates in both countries for both male and female-headed households. One may conclude that non-farm activities are therefore equally important for men and women. However, non-farm 
activities are particularly important to women's welfare as evidenced by women's greater and faster growing participation in non-farm activities. Women in both countries, especially female heads of households, increased their participation in non-farm activities over the periods examined more so than men.

The most interesting aspect of this finding is that the bulk of women's increased participation in non-farm activities comes from female spouses and household heads who add non-farm work as a secondary activity. This is true for both countries. Spouses and household heads were also more likely to be involved in a combination of agriculture and non-farm activities than men were. The other women in the households were found to either maintain or even increase their time in agriculture, apparently taking over duties once done by the female head or spouse. The patterns displayed by the spouses and heads could be interpreted to mean that these women worked more than men, with the added non-farm work being an extra burden, or it could reflect women having less rigid ties to their main agricultural duties and more flexibility to diversify. Whichever is the case, the data show that participation in non-farm activities is strongly linked to reduced poverty, and that this linkage is beneficial to women.

The most striking difference between Ghana and Uganda is in the greater participation of women in agriculture in Uganda and their correspondingly lower participation in non-farm activities. The greater participation of Ghanaian women in nonfarm self-employment conforms more easily to the culturally accepted role of women as market traders. In Uganda, women's traditional role is on the farm, and that is reflected in the participation rates found in this paper. However, Ugandan women have clearly started to diversify into non-farm activities. The examination of secondary activities of 
Ugandan women reveal a large increase from 1992 to 1996 in participation in non-farm activities. Also, the much higher participation of Ugandan female heads (and members of female-headed households) in non-farm activities is an important sign that Ugandan women are taking on non-farm opportunities when they can.

In Ghana, the only country for which we have detailed individual level data, nonfarm income may be giving women added bargaining power in the household. Average incomes from non-farm activities for women were higher than incomes from agriculture, and more importantly, income shares from non-farm activities increased for Ghanaian women, especially female heads and spouses, more so than for men. Comparable data is not available for Uganda, but participation and poverty rate trends suggest a similar trend, though maybe not as marked as in Ghana where women are more active in the non-farm sector.

What leads people to choose to participate in non-farm or agriculture or both? Our analysis of the joint determinants of participation corroborates the main findings in the literature. Higher levels of education lead to greater participation in non-farm activities and lower participation in agriculture. Non-labor income is an important factor explaining non-farm participation in Ghana, but not in Uganda. There is some evidence that a higher dependency ratio is more important as a determinant of women's participation, and that it leads to a larger increase in participation in non-farm activities. But there is also some evidence that a higher dependency ratio is linked to higher participation in agriculture (for both men and women), so overall it is not a robust determinant. We were able to show for Ghana that distance to markets is linked to 
participation in both sectors. The inclusion of different crop acreage in the Ghana regressions helps explain the linkages between agriculture and non-farm participation.

The econometric analysis shows that in both countries, female heads of households are significantly more likely to work in the non-farm sector and significantly less likely to work in agriculture. In Ghana, non-farm work is especially important for all women. In Uganda, the strongly significant result for female heads of household suggests that women who are on their own have made significant inroads into the non-farm sector. We have to interpret this with some caution however, because rather than being a choice, participation in non-farm work may be necessary if the female household head does not have access to land. Given the very inequitable access to land by men and women in Uganda, this may be a real barrier. Nevertheless, the association of lower poverty rates for those female headed households in non-farm work shows that non-farm work is linked with higher standards of living at least at the lower income deciles. Another important aspect of the gender differences in Uganda compared to Ghana, however, is that Ugandan men are much more likely to participate in the non-farm sector than are Ghanaian men. The overall impression given by the Uganda data, from all of the angles of analysis on poverty, income, and participation, is that both men and women have gained from non-farm work in Uganda, with men gaining more on balance.

Further research is needed to better understand the distributional implications of non-farm work by gender. In upcoming work, we examine the role of non-farm income in income inequality and changes over time. 


\section{Annex 1: The Bivariate Model}

A bivariate probit model allows for the existence of possible correlated disturbances between two probit equations. It also allows for testing of whether this joint estimation makes significant difference as opposed to estimating univariate probits for each decision. In the bivariate probit, let the latent variable $y_{1}^{*}$ represent the decision of working in agriculture and $y_{2}^{*}$ represent the decision of working in a non-farm activity. Therefore the general specification for a two-equation model would be

$\mathrm{y}_{1}^{*}=\beta_{1}^{\prime} X+\varepsilon_{1}, \quad \mathrm{y}_{1}=1$ if $y_{1}^{*}>0,0$ otherwise

$y_{2}^{*}=\beta_{2}^{\prime} X+\varepsilon_{2}, \quad y_{2}=1$ if $\mathrm{y}_{2}^{*}>0,0$ otherwise,

$E\left[\varepsilon_{1}\right]=E\left[\varepsilon_{2}\right]=0$,

$\operatorname{Var}\left[\varepsilon_{1}\right]=\operatorname{Var}\left[\varepsilon_{2}\right]=1$,

$\operatorname{Cov}\left[\varepsilon_{1}, \varepsilon_{2}\right]=\rho$.

and the likelihood function to maximize is

$$
L=\prod \int_{-\infty}^{\beta_{1}^{\prime} X_{1}} \int_{-\infty}^{\beta_{2}^{\prime} x_{2}} \phi_{2}\left(z_{1}, z_{2} ; \rho\right) d z_{2} d z_{1}
$$

where $\phi_{2}$, the bivariate normal density function, is

$$
\phi_{2}\left(z_{1}, z_{2} ; \rho\right)=\left[2 \pi\left(1-\rho^{2}\right)^{1 / 2}\right]^{-1} \exp \left[-(1 / 2)\left(1-\rho^{2}\right)^{-1}\left(z_{1}^{2}+z_{2}^{2}-2 \rho z_{1} z_{2}\right)\right]
$$

and

$\rho$ - coefficient of correlation between the two equations.

$\mathrm{X}_{1}$ and $\mathrm{X}_{2}$ - row vectors of exogenous variables

$\beta_{1}$ and $\beta_{2}$ - associated parameter column vectors. 


\section{References}

Abdulai, A. and C. L. Delgado. 1999. "Determinants of nonfarm earnings of farm-based husbands and wives in Northern Ghana," American Journal of Agricultural Economics 81 (1), 117-130.

Adams, Richard H., Jr. 1994. "Non-Farm Income and Inequality in Rural Pakistan: A Decomposition Analysis," Journal of Development Studies (October) 31 (1): pp. 110-133.

Adams, Richard H., Jr. 1999. "Non-Farm Income, Inequality, and Land in Rural Egypt" Policy Research Working Paper, 2178. The World Bank: September.

Appleton, Simon. 1999. "Changes in poverty in Uganda, 1992-1997" (mimeo), May.

Appleton, Simon. 1996. "Women-Headed Households and Household Welfare: An Empirical Deconstruction for Uganda,", World Development 24 (12) 1811-27.

Behrman, Jere R. and Barbara L. Wolfe. 1984. "Labor Force Participation and Earnings Determinants for Women in the Special Conditions of Developing Countries," Journal of Development Economics (Netherlands) (May-August) 15: pp.259-288.

Bhushan, Indu and Shiyan Chao. "Measurement Issues in Gender-Based Poverty Comparisons: Lessons from Ghana” (mimeo), June 1997.

Brown, Lynn R. and Joanna Kerr. 1997. The Gender Dimensions of Economic Reforms in Ghana, Mali, and Zambia The North-South Institute, Ottawa, Ontario.

Canagarajah, S., D. Mazumdar, and Ye Xiao. 1998. The Structure and Determinants of Inequality and Poverty Reduction in Ghana, World Bank Policy Research Working Paper Series no. 1998, Washington DC.

Cleaver, Kevin M. and W. Graeme Donovan. 1995. "Agriculture, Poverty, and Policy Reform in Sub-Saharan Africa" World Bank Technical Discussion Papers 280, Washington DC.

Coulombe, H. and A. McKay. 1995. "An Analysis of Changes in Poverty in Ghana 1987/88 1991/92." (mimeo) Department of Economics: University of Warwick (April).

Deininger, K. and J. Okidi. 1999. "Determinants of Agricultural Productivity and Non-Farm Enterprise Startups: The Case of Uganda." (mimeo) September.

Hazell, Peter and Steven Haggblade. 1993. "Farm-Nonfarm Growth Linkages and the Welfare of the Poor" in Lipton and Van der Gaag (eds) Including the Poor, Washington DC: The World Bank.

Lanjouw, Peter. 1998. "Ecuador's Rural Nonfarm Sector as a Route Out of Poverty" Policy Research Working Paper, 1094. The World Bank: March.

Lanjouw, Jean O. and Peter Lanjouw. 1995. "Rural Nonfarm Employment: A Survey" " Policy Research Working Paper, 1463. The World Bank: May. 
Lloyd, Cynthia B. and Anastasia J. Brandon. 1991. "Women's Role in Maintaining Households: Poverty and Gender Inequality in Ghana" Population Council Research Division Working Paper 25, New York.

Mugyenyi, Mary R. 1998. "Towards the empowerment of women: a critique of NRM policies and programmes" in ed. Holger Bernt Hansen and Michael Twaddle, Developing Uganda Oxford: James Currey Ltd, p. 133-144.

Ranis, Gustav and Frances Stewart. 1993. "Rural Nonagricultural Activities in Development: Theory and Application" Journal of Development Economics Vol. 40: pp. 75-101.

Huppi, Monika and Martin Ravallion. 1991. "The Sectoral Structure of Poverty During an Adjustment Period: Evidence for Indonesia in the Mid-1980s" World Development, Vol. 19, No. 12, pp.1653-78.

Louat, Grosh and van der Gaag. 1993. "Welfare Implications of Female Headship in Jamaican Households" Living Standards Measurement Study Working Paper No. 96. The World Bank.

Mason, Andrew and Jacqueline Baptist. 1996. "How Important Are Labor Markets to the Welfare of Indonesia's Poor?" Policy Research Working Paper, 1665. The World Bank: October.

Reardon, Thomas. 1997. "Using Evidence of Household Income Diversification to Inform Study of the Rural Nonfarm Labor Market in Africa" World Development Vol. 25 (5).

Reardon, Thomas and J. Edward Taylor. 1996. "Agroclimactic Shock, Income Inequality, and Poverty: Evidence from Burkina Faso," World Development Vol. 24 (5): pp. 901-914.

Rosenhouse, Sandra. 1989. "Identifying the Poor: Is "Headship" a Useful Concept?" Living Standards Measurement Study Working Paper No. 58. The World Bank.

Quisumbing, Agnes R., Lawrence Haddad, and Christine Peña. 1995. "Gender and Poverty: New Evidence from Ten Developing Countries" Food Consumption and Nutrition Division Discussion Paper No.9, International Food Policy Research Institute, December.

van de Walle, Dominique. 1994. "Rural Poverty in an Emerging Market Economy: Is Diversification into Nonfarm Activities in Rural Viet Nam the Solution?' Policy Research Department. The World Bank, mimeo.

World Bank. 1997. "Bangladesh: The Non-Farm Sector in a Diversifying Rural Economy" Report No. 16740-BD.

World Bank. 1994. "The Many Faces of Poverty." Status Report on Poverty in Sub-Saharan Africa. Technical Department, Africa Region. 
Table 1: Ghana and Uganda-Poverty Measures by Region and Gender of Household Head

\begin{tabular}{|c|c|c|c|c|c|c|c|c|}
\hline \multirow[b]{2}{*}{ Ghana } & \multicolumn{2}{|c|}{ Population Share } & \multicolumn{2}{|c|}{$\begin{array}{c}\text { Incidence of } \\
\text { Poverty } P_{0}\end{array}$} & \multicolumn{2}{|c|}{$\begin{array}{c}\text { Depth of Poverty } \\
P_{I}\end{array}$} & \multicolumn{2}{|c|}{$\begin{array}{l}\text { Severity of Poverty } \\
P_{2}\end{array}$} \\
\hline & $87 / 88$ & $91 / 92$ & $87 / 88$ & 91/92 & $87 / 88$ & $91 / 92$ & $87 / 88$ & $91 / 92$ \\
\hline National & 100.0 & 100.0 & 36.6 & 31.4 & 11.7 & 8.1 & 5.2 & 3.0 \\
\hline Accra & 8.2 & 8.2 & 8.6 & 23.0 & 1.7 & 5.6 & 0.5 & 1.9 \\
\hline Other Urban & 26.0 & 25.0 & 33.4 & 27.7 & 10.1 & 7.1 & 4.5 & 2.7 \\
\hline Rural & 65.8 & 66.8 & 41.3 & 33.9 & 13.6 & 8.7 & 6.1 & 3.2 \\
\hline FHH & 29.1 & 32.1 & 33.2 & 21.5 & 9.9 & 5.4 & 4.0 & 2.0 \\
\hline $\mathrm{MHH}$ & 70.9 & 67.9 & 24.5 & 22.8 & 7.8 & 5.6 & 3.4 & 2.0 \\
\hline Rural FHH & 28.2 & 28.8 & 37.4 & 23.3 & 11.3 & 5.6 & 4.6 & 2.0 \\
\hline Rural MHH & 71.8 & 71.2 & 30.4 & 25.1 & 9.7 & 6.2 & 4.3 & 2.2 \\
\hline
\end{tabular}

\begin{tabular}{lrlllllll}
\hline & Population Share & \multicolumn{2}{c}{$\begin{array}{c}\text { Incidence of } \\
\text { Poverty } P_{0}\end{array}$} & \multicolumn{2}{c}{$\begin{array}{c}\text { Depth of Poverty } \\
P_{1}\end{array}$} & \multicolumn{2}{c}{$\begin{array}{c}\text { Severity of Poverty } \\
P_{2}\end{array}$} \\
Uganda & $\mathbf{1 9 9 2}$ & $\mathbf{1 9 9 6}$ & $\mathbf{1 9 9 2}$ & $\mathbf{1 9 9 6}$ & $\mathbf{1 9 9 2}$ & $\mathbf{1 9 9 6}$ & $\mathbf{1 9 9 2}$ & $\mathbf{1 9 9 6}$ \\
\hline National & 1.00 & 1.00 & 57.4 & 45.8 & 21.6 & 14.7 & 10.7 & 6.5 \\
Urban & 9.6 & 10.2 & 24.7 & 14.5 & 6.9 & 3.6 & 2.7 & 1.3 \\
Other Urban & 3.4 & 3.1 & 38.0 & 30.0 & 12.6 & 8.7 & 5.5 & 3.6 \\
Rural & $\mathbf{8 7 . 0}$ & 86.7 & 61.8 & 50.4 & 23.6 & 16.4 & 11.8 & 7.2 \\
FHH & 22.9 & 23.7 & 56.1 & 48.1 & 21.0 & 16.7 & 10.4 & 7.7 \\
MHH & 77.1 & 76.3 & 57.7 & 45.1 & 21.7 & 14.1 & 10.7 & 6.0 \\
Rural FHH & 22.3 & 23.0 & 60.4 & 53.4 & 23.2 & 18.8 & 11.6 & 8.7 \\
Rural MHH & 77.7 & 77.0 & 62.2 & 49.6 & 23.7 & 15.6 & 11.8 & 6.8 \\
\hline
\end{tabular}

Table 2: Ghana and Uganda-Percentage Change in Poverty Measures by Region and Gender

\begin{tabular}{l|cccc|cccc}
\hline & \multicolumn{4}{|c|}{ Ghana } & \multicolumn{4}{c}{ Uganda } \\
& Pop. & Incidence & Depth & Severity & Pop. & Incidence & Depth & Severity \\
\hline National & -- & -0.14 & -0.31 & -0.42 & - & -0.20 & -0.32 & -0.39 \\
Urban & 0.00 & 1.67 & 2.29 & 2.80 & 0.06 & -0.41 & -0.48 & -0.52 \\
Other Urban & -0.04 & -0.17 & -0.30 & -0.40 & -0.09 & -0.21 & -0.31 & -0.35 \\
Rural & 0.02 & -0.18 & -0.36 & -0.48 & 0.00 & -0.18 & -0.31 & -0.39 \\
& & & & & & & & \\
FHH & 0.10 & -0.35 & -0.45 & -0.50 & 0.03 & -0.14 & -0.20 & -0.26 \\
MHH & -0.04 & -0.07 & -0.28 & -0.41 & -0.01 & -0.22 & -0.35 & -0.44 \\
Rural FHH & 0.02 & -0.38 & -0.50 & -0.57 & 0.03 & -0.12 & -0.19 & -0.25 \\
Rural MHH & -0.01 & -0.17 & -0.36 & -0.49 & -0.01 & -0.20 & -0.34 & -0.42 \\
\hline
\end{tabular}


Table 3: Rural Poverty Changes by Agriculture/Non-farm Rural Industry: Ghana and Uganda

\begin{tabular}{lrrrrrrrrrrr} 
& \multicolumn{1}{c}{ Pop. Share } & \multicolumn{3}{c}{ Incidence } & \multicolumn{4}{c}{ Depth } & \multicolumn{3}{c}{ Severity } \\
Ghana & $\mathbf{8 7 / 8 8}$ & $\mathbf{9 1 / 9 2}$ & $\mathbf{8 7 / 8 8}$ & $\mathbf{9 1 / 9 2}$ & $\mathbf{\% \Delta}$ & $\mathbf{8 7 / 8 8}$ & $\mathbf{9 1 / 9 2}$ & $\% \Delta$ & $\mathbf{8 7 / 8 8}$ & $\mathbf{9 1 / 9 2}$ & $\% \Delta$ \\
\hline Agriculture-main job & 80.4 & 79.2 & 41.2 & 31.9 & -0.23 & 13.8 & 8.2 & -0.41 & 6.3 & 3 & -0.52 \\
Non-farm-main job & 29.6 & 20.8 & 27.2 & 20.6 & -0.24 & 7.7 & 4.9 & -0.36 & 3 & 1.7 & -0.43 \\
Any agriculture & 91.4 & 88.7 & 39.4 & 30.6 & -0.22 & 12.9 & 7.8 & -0.40 & 5.8 & 2.8 & -0.52 \\
Any non-farm & 37.7 & 35.6 & 31.7 & 24.0 & -0.24 & 9.5 & 6.0 & -0.37 & 3.9 & 2.2 & -0.44 \\
Agriculture only & 62.0 & 64.4 & 42.7 & 32.7 & -0.23 & 14.5 & 8.3 & -0.43 & 6.7 & 3.0 & -0.55 \\
Non-farm only & 8.2 & 11.3 & 28.5 & 21.3 & -0.25 & 9.1 & 5.2 & -0.43 & 3.6 & 1.8 & -0.50 \\
Both AG and NF & 29.5 & 24.4 & 32.5 & 25.3 & -0.22 & 9.6 & 6.4 & -0.33 & 4.0 & 2.3 & -0.43 \\
\hline
\end{tabular}

\begin{tabular}{|c|c|c|c|c|c|c|c|c|c|c|c|}
\hline \multirow[b]{2}{*}{ Uganda } & \multicolumn{2}{|c|}{ Pop. Share } & \multicolumn{3}{|c|}{ Incidence } & \multicolumn{3}{|c|}{ Depth } & \multicolumn{3}{|c|}{ Severity } \\
\hline & 1992 & 1996 & 1992 & 1996 & $\% \Delta$ & 1992 & 1996 & $\% \Delta$ & 1992 & 1996 & $\% \Delta$ \\
\hline Agriculture-main job & 85.6 & 84.0 & 64.0 & 50.9 & -0.20 & 24.5 & 16.5 & -0.33 & 12.3 & 7.3 & -0.41 \\
\hline Non-farm-main job & 14.4 & 16.0 & 46.3 & 31.8 & -0.31 & 16.3 & 9.1 & -0.44 & 7.9 & 3.7 & -0.53 \\
\hline Any agriculture & 91.2 & 92.6 & 62.9 & 49.5 & -0.21 & 24.0 & 16.0 & -0.33 & 12.0 & 7.1 & -0.41 \\
\hline Any non-farm & 27.0 & 39.0 & 54.4 & 39.8 & -0.27 & 19.9 & 12.0 & -0.40 & 9.7 & 5.1 & -0.47 \\
\hline Agriculture only & 73.0 & 60.8 & 64.0 & 53.0 & -0.17 & 24.6 & 17.4 & -0.29 & 12.4 & 7.7 & -0.38 \\
\hline Non-farm only & 8.8 & 7.2 & 46.3 & 26.9 & -0.42 & 16.9 & 6.9 & -0.59 & 8.4 & 2.5 & -0.70 \\
\hline Both $A G$ and NF & 18.2 & 31.8 & 58.5 & 42.9 & -0.27 & 21.4 & 13.2 & -0.38 & 10.4 & 5.7 & -0.45 \\
\hline
\end{tabular}

Table 4: Rural Poverty by Gender and Agriculture/Nonfarm Sector*

\begin{tabular}{|c|c|c|c|c|c|c|c|c|c|c|}
\hline \multirow[b]{3}{*}{ Ghana } & \multicolumn{5}{|c|}{$F H H$} & \multicolumn{5}{|c|}{$M H H$} \\
\hline & \multicolumn{2}{|c|}{ Pop. Share } & \multicolumn{3}{|c|}{ Incidence } & \multicolumn{2}{|c|}{ Pop. share } & \multicolumn{3}{|c|}{ Incidence } \\
\hline & $87 / 88$ & $91 / 92$ & $87 / 88$ & $91 / 92$ & $\% \Delta$ & $87 / 88$ & 91/92 & $87 / 88$ & $91 / 92$ & $\% \Delta$ \\
\hline Agriculture-main job & 69.4 & 63.9 & 0.51 & 0.37 & -0.27 & 76.1 & 74.9 & 0.41 & 0.37 & -0.10 \\
\hline Non-farm-main job & 30.6 & 36.1 & 0.34 & 0.22 & -0.35 & 23.9 & 25.1 & 0.29 & 0.24 & -0.17 \\
\hline Any agriculture & 86.0 & 78.8 & 37.7 & 25.3 & -0.33 & 93.7 & 90.5 & 31.0 & 26.4 & -0.15 \\
\hline Any non-farm & 55.8 & 56.3 & 32.8 & 20.3 & -0.38 & 44.0 & 39.7 & 23.1 & 18.9 & -0.18 \\
\hline Agriculture only & 0.44 & 0.44 & 40.9 & 28.1 & -0.31 & 0.56 & 0.60 & 36.1 & 29.5 & -0.18 \\
\hline Non-farm only & 0.14 & 0.21 & 28.4 & 17.8 & -0.37 & 0.06 & 0.09 & 20.8 & 14.2 & -0.32 \\
\hline Both $\mathrm{AG}$ and NF & 0.42 & 0.35 & 34.4 & 21.8 & -0.37 & 0.39 & 0.30 & 23.5 & 20.3 & -0.14 \\
\hline
\end{tabular}

\begin{tabular}{|c|c|c|c|c|c|c|c|c|c|c|}
\hline \multirow[b]{3}{*}{ Uganda } & \multicolumn{5}{|c|}{$F H H$} & \multicolumn{5}{|c|}{$M H H$} \\
\hline & \multicolumn{2}{|c|}{ Pop. Share } & \multicolumn{3}{|c|}{ Incidence } & \multicolumn{2}{|c|}{ Pop. share } & \multicolumn{3}{|c|}{ Incidence } \\
\hline & 1992 & 1996 & 1992 & 1996 & $\% \Delta$ & 1992 & 1996 & 1992 & 1996 & $\% \Delta$ \\
\hline Agriculture-main job & 87.3 & 85.6 & 57.9 & 48.1 & -0.17 & 74.1 & 73.2 & 61.4 & 46.8 & -0.24 \\
\hline Non-farm-main job & 12.7 & 14.5 & 40.2 & 28.6 & -0.29 & 25.9 & 26.8 & 39.8 & 29.3 & -0.26 \\
\hline Any agriculture & 91.1 & 94.2 & 57.0 & 46.8 & -0.18 & 87.1 & 89.1 & 58.6 & 44.4 & -0.24 \\
\hline Any non-farm & 28.0 & 46.0 & 52.4 & 41.9 & -0.20 & 50.1 & 50.8 & 49.1 & 33.9 & -0.31 \\
\hline Agriculture only & 0.73 & 0.55 & 56.8 & 48.4 & -0.15 & 0.50 & 0.48 & 62.4 & 50.9 & -0.18 \\
\hline Non-farm only & 0.09 & 0.05 & 40.9 & 23.1 & -0.44 & 0.13 & 0.11 & 37.1 & 23.4 & -0.37 \\
\hline Both $A G$ and $N F$ & 0.18 & 0.39 & 57.9 & 44.4 & -0.23 & 0.37 & 0.41 & 53.4 & 36.8 & -0.31 \\
\hline
\end{tabular}


Table 6: Participation trends by industry grouping: Uganda

\begin{tabular}{|c|c|c|c|c|c|c|c|c|}
\hline & \multicolumn{4}{|c|}{1992} & \multicolumn{4}{|c|}{1996} \\
\hline Industry grouping: Men & \multicolumn{2}{|c|}{ Main } & \multicolumn{2}{|c|}{ Secondary } & \multicolumn{2}{|c|}{ Main } & \multicolumn{2}{|c|}{ Secondary } \\
\hline & Obs & $\%$ & Obs & $\%$ & Obs & $\%$ & Obs & $\%$ \\
\hline Agri/Livestock/Agri Services & 4720 & 80.27 & 2301 & 71.37 & 2455 & 75.35 & 1034 & 57.89 \\
\hline Fish/Forest/Mining & 126 & 2.14 & 125 & 3.88 & 100 & 3.07 & 96 & 5.38 \\
\hline Manuf: Food/Beverages/Tobacco & 65 & 1.11 & 115 & 3.57 & 51 & 1.57 & 101 & 5.66 \\
\hline Manuf:Textil./Wood/Leather/Handicraft & 88 & 1.50 & 118 & 3.66 & 69 & 2.12 & 136 & 7.61 \\
\hline Manuf: Paper/Chem/Metal/Nonmetal & 43 & 0.73 & 74 & 2.30 & 41 & 1.26 & 71 & 3.98 \\
\hline Util/Cons/Trans \& Comm. & 154 & 2.62 & 64 & 1.99 & 112 & 3.44 & 68 & 3.81 \\
\hline Wholesale/Retail Trade & 227 & 3.86 & 239 & 7.41 & 185 & 5.68 & 189 & 10.58 \\
\hline Restaurant/Repair/Other Services & 77 & 1.31 & 88 & 2.73 & 71 & 2.18 & 54 & 3.02 \\
\hline Pub. Admin/Education & 303 & 5.15 & 26 & 0.81 & 138 & 4.24 & 11 & 0.62 \\
\hline Prof. \& Financial Services & 77 & 1.31 & 74 & 2.30 & 36 & 1.10 & 26 & 1.46 \\
\hline Total & 5880 & 100 & 3224 & 100 & 3258 & 100 & 1786 & 100 \\
\hline Industry grouping: Women & \multicolumn{2}{|c|}{ Main } & \multicolumn{2}{|c|}{ Secondary } & \multicolumn{2}{|c|}{ Main } & \multicolumn{2}{|c|}{ Secondary } \\
\hline & Obs & $\%$ & Obs & $\%$ & Obs & $\%$ & Obs & $\%$ \\
\hline Agri/Livestock/Agri Services & 5691 & 94.33 & 1407 & 71.86 & 3543 & 91.84 & 530 & 35.19 \\
\hline Fish/Forest/Mining & 17 & 0.28 & 14 & 0.72 & 31 & 0.80 & 92 & 6.11 \\
\hline Manuf: Food/Beverages/Tobacco & 44 & 0.73 & 344 & 17.57 & 53 & 1.37 & 283 & 18.79 \\
\hline Manuf:Textil./Wood/Leather/Handicraft & 44 & 0.73 & 86 & 4.39 & 35 & 0.91 & 403 & 26.76 \\
\hline Manuf: Paper/Chem/Metal/Nonmetal & 5 & 0.08 & 2 & 0.10 & 5 & 0.13 & 16 & 1.06 \\
\hline Util/Cons/Trans \& Comm. & 8 & 0.13 & 2 & 0.10 & 10 & 0.26 & 11 & 0.73 \\
\hline Wholesale/Retail Trade & 66 & 1.09 & 60 & 3.06 & 74 & 1.92 & 110 & 7.30 \\
\hline Restaurant/Repair/Other Services & 46 & 0.76 & 30 & 1.53 & 58 & 1.50 & 55 & 3.65 \\
\hline Pub. Admin/Education & 88 & 1.46 & 4 & 0.20 & 30 & 0.78 & 1 & 0.07 \\
\hline Prof. \& Financial Services & 24 & 0.40 & 9 & 0.46 & 19 & 0.49 & 5 & 0.33 \\
\hline Total & 6033 & 100 & 1958 & 100 & 3858 & 100 & 1506 & 100 \\
\hline
\end{tabular}

Table 7: Participation trends by industry grouping: Ghana

\begin{tabular}{|c|c|c|c|c|c|c|c|c|}
\hline & \multicolumn{4}{|c|}{$1987 / 88$} & \multicolumn{4}{|c|}{ 1991/92 } \\
\hline Industry grouping: Men & \multicolumn{2}{|c|}{ Main } & \multicolumn{2}{|c|}{ Secondary } & \multicolumn{2}{|c|}{ Main } & \multicolumn{2}{|c|}{ Secondary } \\
\hline & Obs & $\%$ & Obs & $\%$ & Obs & $\%$ & Obs & $\%$ \\
\hline Agri/Livestock/Agri Services & 2144 & 84.14 & 391 & 52.13 & 2675 & 82.92 & 377 & 53.48 \\
\hline Fish/Forest/Mining & 80 & 3.14 & 64 & 8.53 & 89 & 2.76 & 24 & 3.4 \\
\hline Manuf: Food/Beverages/Tobacco & 24 & 0.94 & 58 & 7.73 & 23 & 0.71 & 74 & 10.5 \\
\hline Manuf:Textil./Wood/Leather/Handicraft & 39 & 1.53 & 36 & 4.8 & 63 & 1.95 & 55 & 7.8 \\
\hline Manuf: Paper/Chem/Metal/Nonmetal & 15 & 0.59 & 34 & 4.53 & 27 & 0.84 & 30 & 4.26 \\
\hline Util/Cons/Trans \& Comm. & 47 & 1.84 & 28 & 3.73 & 79 & 2.45 & 29 & 4.11 \\
\hline Wholesale/Retail Trade & 36 & 1.41 & 72 & 9.6 & 56 & 1.74 & 71 & 10.07 \\
\hline Restaurant/Repair/Other Services & 39 & 1.53 & 45 & 6 & 36 & 1.12 & 21 & 2.98 \\
\hline Pub. Admin/Education & 89 & 3.49 & 8 & 1.07 & 123 & 3.81 & 5 & 0.71 \\
\hline Prof. \& Financial Services & 35 & 1.37 & 14 & 1.87 & 55 & 1.7 & 19 & 2.7 \\
\hline Total & 2548 & 100 & 750 & 100 & 3226 & 100 & 705 & 100 \\
\hline Industry grouping: Women & \multicolumn{2}{|c|}{ Main } & \multicolumn{2}{|c|}{ Secondary } & \multicolumn{2}{|c|}{ Main } & \multicolumn{2}{|c|}{ Secondary } \\
\hline & Obs & $\%$ & Obs & $\%$ & Obs & $\%$ & Obs & $\%$ \\
\hline Agri/Livestock/Agri Services & 2183 & 80.23 & 300 & 33.67 & 2793 & 78.61 & 299 & 29.49 \\
\hline Fish/Forest/Mining & 8 & 0.29 & 52 & 5.84 & 5 & 0.14 & 0 & 0 \\
\hline Manuf: Food/Beverages/Tobacco & 124 & 4.56 & 146 & 16.39 & 155 & 4.36 & 199 & 19.63 \\
\hline Manuf:Textil./Wood/Leather/Handicraft & 35 & 1.29 & 26 & 2.92 & 39 & 1.1 & 15 & 1.48 \\
\hline Manuf: Paper/Chem/Metal/Nonmetal & 20 & 0.74 & 25 & 2.81 & 18 & 0.51 & 63 & 6.21 \\
\hline Util/Cons/Trans \& Comm. & 2 & 0.07 & 3 & 0.34 & 2 & 0.06 & 1 & 0.1 \\
\hline Wholesale/Retail Trade & 257 & 9.45 & 302 & 33.89 & 439 & 12.36 & 420 & 41.42 \\
\hline Restaurant/Repair/Other Services & 35 & 1.29 & 33 & 3.7 & 45 & 1.27 & 12 & 1.18 \\
\hline Pub. Admin/Education & 36 & 1.32 & 2 & 0.22 & 49 & 1.38 & 1 & 0.1 \\
\hline Prof. \& Financial Services & 21 & 0.77 & 2 & 0.22 & 8 & 0.23 & 4 & 0.39 \\
\hline Total & 2721 & 100 & 891 & 100 & 3553 & 100 & 1014 & 100 \\
\hline
\end{tabular}


Table 8: Main and Secondary Occupations-- Rural Ghana

\begin{tabular}{|c|c|c|c|c|c|c|c|c|}
\hline \multirow{3}{*}{$\begin{array}{l}\text { Main Occupation } \\
\quad+\text { Secondary occupation }\end{array}$} & \multicolumn{2}{|c|}{1987} & \multicolumn{2}{|c|}{1991} & \multicolumn{2}{|c|}{1987} & \multicolumn{2}{|c|}{1991} \\
\hline & \multicolumn{4}{|c|}{ Men } & \multicolumn{4}{|c|}{ Women } \\
\hline & Obs & $\%$ & $O b s$ & $\%$ & Obs & $\%$ & Obs & $\%$ \\
\hline Farming & 1408 & 62.9 & 2208 & 70.1 & 1243 & 54.4 & 1981 & 57.8 \\
\hline + Wage employment & 114 & 5.1 & 64 & 2.0 & 31 & 1.4 & 10 & 0.3 \\
\hline+ Self-employment & 239 & 10.7 & 266 & 8.4 & 477 & 20.9 & 661 & 19.3 \\
\hline Wage employment & 72 & 3.2 & 130 & 4.1 & 26 & 1.1 & 37 & 1.1 \\
\hline + Farming & 201 & 9.0 & 216 & 6.9 & 50 & 2.2 & 37 & 1.1 \\
\hline Self-employment & 48 & 2.1 & 102 & 3.2 & 209 & 9.1 & 426 & 12.4 \\
\hline + Farming & 89 & 4.0 & 124 & 3.9 & 212 & 9.3 & 259 & 7.6 \\
\hline Subtotal & 2171 & 97.0 & 3110 & 98.8 & 2248 & 98.3 & 3411 & 99.5 \\
\hline All other & 66 & 3.0 & 38 & 1.2 & 38 & 1.7 & 17 & 0.5 \\
\hline \multirow[t]{3}{*}{ TOTAL } & 2237 & 100 & 3148 & 100 & 2286 & 100 & 3428 & 100 \\
\hline & \multicolumn{4}{|c|}{ Male Household Heads } & \multicolumn{4}{|c|}{ Female Household Heads } \\
\hline & $O b s$ & $\%$ & $O b s$ & $\%$ & Obs & $\%$ & $O b s$ & $\%$ \\
\hline Farming & 640 & 52.2 & 1212 & 60.0 & 151 & 36.2 & 323 & 41.8 \\
\hline + Wage employment & 63 & 5.1 & 59 & 2.9 & 5 & 1.2 & 8 & 1.0 \\
\hline + Self-employment & 183 & 14.9 & 236 & 11.7 & 102 & 24.5 & 153 & 19.8 \\
\hline Wage employment & 46 & 3.8 & 100 & 4.9 & 11 & 2.6 & 20 & 2.6 \\
\hline + Farming & 166 & 13.6 & 203 & 10.0 & 21 & 5.0 & 16 & 2.1 \\
\hline Self-employment & 22 & 1.8 & 73 & 3.6 & 46 & 11.0 & 137 & 17.7 \\
\hline + Farming & 54 & 4.4 & 103 & 5.1 & 65 & 15.6 & 103 & 13.3 \\
\hline Subtotal & 1174 & 95.8 & 1986 & 98.3 & 401 & 96.2 & 760 & 98.3 \\
\hline All other & 51 & 4.2 & 35 & 1.7 & 16 & 3.8 & 13 & 1.7 \\
\hline \multirow[t]{3}{*}{ TOTAL } & 1225 & 100 & 2021 & 100 & 417 & 100 & 773 & 100 \\
\hline & \multicolumn{4}{|c|}{ Female Spouses } & \multicolumn{4}{|c|}{ Females (not HHd or spouse) } \\
\hline & Obs & $\%$ & $O b s$ & $\%$ & $O b s$ & $\%$ & $O b s$ & $\%$ \\
\hline Farming & 618 & 55.8 & 958 & 55.4 & 473 & 62.1 & 698 & 75.5 \\
\hline + Wage employment & 11 & 1.0 & 1 & 0.1 & 15 & 2.0 & 1 & 0.1 \\
\hline + Self-employment & 278 & 25.1 & 420 & 24.3 & 97 & 12.7 & 88 & 9.5 \\
\hline Wage employment & 5 & 0.5 & 11 & 0.6 & 10 & 1.3 & 6 & 0.6 \\
\hline + Farming & 17 & 1.5 & 14 & 0.8 & 12 & 1.6 & 7 & 0.8 \\
\hline Self-employment & 72 & 6.5 & 194 & 11.2 & 91 & 11.9 & 95 & 10.3 \\
\hline + Farming & 92 & 8.3 & 129 & 7.5 & 55 & 7.2 & 27 & 2.9 \\
\hline Subtotal & 1093 & 98.7 & 1727 & 99.9 & 753 & 98.8 & 922 & 99.8 \\
\hline All other & 14 & 1.3 & 2 & 0.1 & 9 & 1.2 & 2 & 0.2 \\
\hline TOTAL & 1107 & 100 & 1729 & 100 & 762 & 100 & 924 & 100 \\
\hline
\end{tabular}

Source: GLSS1 (1987-88) and GLSS3 (1991-92) 
Table 9: Main and Secondary Occupations--Rural Uganda

\begin{tabular}{|c|c|c|c|c|c|c|c|c|}
\hline \multirow{3}{*}{$\begin{array}{l}\text { Main Occupation } \\
\quad+\text { Secondary occupation }\end{array}$} & \multicolumn{2}{|c|}{1992} & \multicolumn{2}{|c|}{1996} & \multicolumn{2}{|c|}{1992} & \multicolumn{2}{|c|}{1996} \\
\hline & \multicolumn{4}{|c|}{ Men } & \multicolumn{4}{|c|}{ Women } \\
\hline & Obs & $\%$ & Obs & $\%$ & Obs & $\%$ & Obs & $\%$ \\
\hline Farming & 4208 & 60.2 & 1752 & 53.8 & 6118 & 85.4 & 2579 & 66.8 \\
\hline + Wage employment & 603 & 8.6 & 148 & 4.5 & 127 & 1.8 & 31 & 0.8 \\
\hline+ Self-employment & 583 & 8.3 & 538 & 16.5 & 472 & 6.6 & 924 & 24.0 \\
\hline Wage employment & 620 & 8.9 & 173 & 5.3 & 145 & 2.0 & 37 & 1.0 \\
\hline+ Farming & 471 & 7.2 & 212 & 6.5 & 67 & 0.8 & 39 & 1.0 \\
\hline Self-employment & 257 & 3.7 & 158 & 4.9 & 169 & 2.4 & 93 & 2.4 \\
\hline + Farming & 201 & 2.9 & 235 & 7.2 & 55 & 0.8 & 140 & 3.6 \\
\hline Subtotal & 6943 & 99.3 & 3216 & 98.8 & 7147 & 98.8 & 3843 & 96.4 \\
\hline All other & 44 & 0.7 & 41 & 1.2 & 15 & 0.2 & 13 & 0.4 \\
\hline \multirow[t]{3}{*}{ TOTAL } & 6987 & 100 & 3257 & 100 & 7162 & 100 & 3856 & 100 \\
\hline & \multicolumn{4}{|c|}{ Male Household Heads } & \multicolumn{4}{|c|}{ Female Household Heads } \\
\hline & Obs & $\%$ & Obs & $\%$ & Obs & $\%$ & Obs & $\%$ \\
\hline Farming & 2089 & 49.7 & 1183 & 49.1 & 1009 & 72.5 & 476 & 54.0 \\
\hline + Wage employment & 505 & 12.0 & 120 & 5.0 & 54 & 3.9 & 9 & 1.0 \\
\hline + Self-employment & 521 & 12.4 & 460 & 19.1 & 165 & 11.9 & 269 & 30.5 \\
\hline Wage employment & 349 & 8.3 & 109 & 4.5 & 47 & 3.4 & 12 & 1.4 \\
\hline + Farming & 385 & 9.2 & 180 & 7.4 & 23 & 1.7 & 15 & 1.7 \\
\hline Self-employment & 156 & 3.7 & 116 & 4.8 & 61 & 4.4 & 32 & 3.6 \\
\hline + Farming & 167 & 4.0 & 207 & 8.6 & 26 & 1.9 & 63 & 7.1 \\
\hline Subtotal & 4172 & 99.3 & 2375 & 98.7 & 1385 & 99.7 & 876 & 99.3 \\
\hline All other & 34 & 0.7 & 34 & 1.3 & 6 & 0.3 & 6 & 0.7 \\
\hline \multirow[t]{3}{*}{ TOTAL } & 4206 & 100 & 2409 & 100 & 1391 & 100 & 882 & 100 \\
\hline & \multicolumn{4}{|c|}{ Female Spouses } & \multicolumn{4}{|c|}{ Females (not HHd or spouse) } \\
\hline & $O b s$ & $\%$ & Obs & $\%$ & Obs & $\%$ & Obs & $\%$ \\
\hline Farming & 3331 & 89.0 & 1547 & 71.8 & 1785 & 87.7 & 556 & 68.0 \\
\hline + Wage employment & 50 & 1.3 & 15 & 0.7 & 23 & 1.1 & 7 & 0.9 \\
\hline + Self-employment & 222 & 5.9 & 488 & 22.6 & 86 & 4.2 & 167 & 20.4 \\
\hline Wage employment & 41 & 1.1 & 3 & 0.1 & 57 & 2.8 & 22 & 2.7 \\
\hline + Farming & 24 & 0.7 & 8 & 0.4 & 14 & 0.7 & 16 & 1.9 \\
\hline Self-employment & 57 & 1.5 & 38 & 1.8 & 51 & 2.5 & 23 & 2.8 \\
\hline + Farming & 13 & 0.4 & 52 & 2.4 & 16 & 0.8 & 25 & 3.1 \\
\hline Subtotal & 3738 & 99.9 & 2151 & 99.8 & 2032 & 99.8 & 816 & 99.8 \\
\hline All other & 4 & 0.1 & 5 & 0.2 & 5 & 0.2 & 2 & 0.2 \\
\hline TOTAL & 3742 & 100 & 2156 & 100 & 2037 & 100 & 818 & 1000 \\
\hline
\end{tabular}

Source: IHS (1992-93) and NHS-4 (1996-97) 
Table 10: Ghana Real Income (Adjusted values)*

\begin{tabular}{|c|c|c|c|c|c|c|c|c|}
\hline \multirow[t]{2}{*}{1987} & \multicolumn{3}{|c|}{ Men } & \multicolumn{3}{|c|}{ Women } & \multicolumn{2}{|c|}{$\%$ Diff Women/Men } \\
\hline & Obs & Mean & Median & Obs & Mean & Median & Mean & Median \\
\hline $\mathrm{AG}$ & 1984 & 75,803 & 33,623 & 1907 & 50,818 & 23,042 & -33.0 & -31.5 \\
\hline $\mathrm{SE}$ & 267 & 199,272 & 70,956 & 729 & 169,917 & 61,495 & -14.7 & -13.3 \\
\hline Wage & 392 & 217,586 & 188,908 & 116 & 160,461 & 162,588 & -26.3 & -13.9 \\
\hline Total & 2237 & 129,143 & 54,971 & 2286 & 104,721 & 36,866 & -18.9 & -32.9 \\
\hline \multirow[t]{2}{*}{1991} & \multicolumn{3}{|c|}{ Men } & \multicolumn{3}{|c|}{ Women } & \multicolumn{2}{|c|}{$\%$ Diff Women/Men } \\
\hline & Obs & Mean & Median & $O b s$ & Mean & Median & Mean & Median \\
\hline $\mathrm{AG}$ & 2797 & 76,861 & 42,485 & 2861 & 51,892 & 30,792 & -32.5 & -27.5 \\
\hline $\mathrm{SE}$ & 494 & 267,567 & 134,041 & 1346 & 238,836 & 95,519 & -10.7 & -28.7 \\
\hline Wage & 446 & 328,656 & 300,398 & 92 & 222,564 & 227,629 & -32.3 & -24.2 \\
\hline Total & 3148 & 156,482 & 67,303 & 3428 & 143,061 & 55,638 & -8.6 & -17.3 \\
\hline
\end{tabular}

Table 11: Uganda Mean Income (Adjusted values to 1989 prices)

\begin{tabular}{|c|c|c|c|c|c|c|c|c|}
\hline \multirow[t]{2}{*}{1992} & \multicolumn{3}{|c|}{ MHHO } & \multicolumn{3}{|c|}{ FHHO } & \multicolumn{2}{|c|}{$\%$ diff $F H H O / M H H O$} \\
\hline & Obs & Mean & Median & Obs & Mean & Median & Mean & Median \\
\hline AG & 3,954 & 125,391 & 87,983 & 1,300 & 93,945 & 61,878 & -25.1 & -29.7 \\
\hline SE & 1,197 & 117,823 & 51,302 & 370 & 63,875 & 35,517 & -45.8 & -30.8 \\
\hline Wage & 1,417 & 81,975 & 52,091 & 307 & 65,827 & 35,517 & -19.7 & -31.8 \\
\hline Total & 4,323 & 176,135 & 123,441 & 1,424 & 118,005 & 80,446 & -33.0 & -34.8 \\
\hline \multirow[t]{2}{*}{1996} & \multicolumn{3}{|c|}{ MHHO } & \multicolumn{3}{|c|}{ FHHO } & \multicolumn{2}{|c|}{$\%$ diff $F H H O / M H H O$} \\
\hline & Obs & Mean & Median & Obs & Mean & Median & Mean & Median \\
\hline$A G$ & 2,406 & 185,563 & 126,384 & 902 & 114,556 & 78,238 & -38.3 & -38.1 \\
\hline $\mathrm{SE}$ & 875 & 192,557 & 78,238 & 295 & 84,623 & 36,110 & -56.1 & -53.8 \\
\hline Wage & 947 & 147,272 & 72,219 & 199 & 91,682 & 36,110 & -37.7 & -50.0 \\
\hline Total & 4,210 & 304,573 & 203,267 & 1,387 & 160,846 & 108,329 & -47.2 & -46.7 \\
\hline
\end{tabular}

\footnotetext{
* The values shown in both tables are those for which the adjusted income is different from zero. The numbers in each group add up to more than the total number of observations since many have several types of income.
} 
Table 12: Mean Income Shares from Individual Incomes-Ghana

\begin{tabular}{lcccccccc}
\hline Ghana & \multicolumn{2}{c}{ Men } & \multicolumn{2}{c}{ Women } & \multicolumn{2}{c}{ MHH } & \multicolumn{2}{c}{ FHH } \\
Sector & 1987 & 1991 & 1987 & 1991 & 1987 & 1991 & 1987 & 1991 \\
\hline Farm & 0.77 & 0.76 & 0.71 & 0.67 & 0.70 & 0.68 & 0.56 & 0.51 \\
Self-employment & 0.09 & 0.11 & 0.25 & 0.31 & 0.10 & 0.15 & 0.34 & 0.43 \\
Wage employment & 0.14 & 0.13 & 0.04 & 0.02 & 0.20 & 0.17 & 0.10 & 0.06 \\
& & & & & & & & \\
Obs & 2237 & 3148 & 2286 & 3428 & 1225 & 2021 & 417 & 773 \\
\hline Ghana & Married Men & Married Women & Other men & Other Women \\
Sector & 1987 & 1991 & 1987 & 1991 & 1987 & 1991 & 1987 & 1991 \\
\hline Farm & 0.70 & 0.69 & 0.71 & 0.63 & 0.86 & 0.91 & 0.75 & 0.82 \\
Self-employment & 0.10 & 0.14 & 0.25 & 0.34 & 0.07 & 0.05 & 0.22 & 0.17 \\
Wage employment & 0.20 & 0.17 & 0.04 & 0.02 & 0.07 & 0.03 & 0.03 & 0.01 \\
Obs & 1148 & 1718 & 1445 & 2095 & 910 & 1080 & 587 & 794 \\
\hline
\end{tabular}

Table 13 : Mean Income Shares from household incomes

\begin{tabular}{lrlrl}
\hline Ghana & \multicolumn{2}{c}{ MHHO } & \multicolumn{2}{c}{ FHHO } \\
Sector & $\mathbf{1 9 8 7 / 8 8}$ & $\mathbf{1 9 9 1 / 9 2}$ & $\mathbf{1 9 8 7 / 8 8}$ & $\mathbf{1 9 9 1 / 9 2}$ \\
\hline Agriculture & 0.65 & 0.60 & 0.52 & 0.49 \\
Self-employment & 0.18 & 0.25 & 0.34 & 0.44 \\
Wage labour & 0.17 & 0.15 & 0.13 & 0.07 \\
& & & & \\
Obs & 1265 & 2059 & 432 & 783 \\
\hline Uganda & \multicolumn{2}{c}{ MHH0 } & \multicolumn{2}{c}{ FHH0 } \\
Sector & 1992 & 1996 & $\mathbf{1 9 9 2}$ & $\mathbf{1 9 9 6}$ \\
\hline Agriculture & 0.71 & 0.70 & 0.76 & 0.78 \\
Self-employment & 0.12 & 0.14 & 0.12 & 0.13 \\
Wage labour & 0.16 & 0.17 & 0.10 & 0.10 \\
& & & & \\
Obs & 4323 & 2579 & 1424 & 962 \\
\hline
\end{tabular}




\section{Policy Research Working Paper Series}

\begin{tabular}{|c|c|c|c|c|}
\hline & Title & Author & Date & for paper \\
\hline WPS2352 & $\begin{array}{l}\text { How Stronger Patent Protection in } \\
\text { India Might Affect the Behavior } \\
\text { of Transnational Pharmaceutical } \\
\text { Industries }\end{array}$ & Carsten Fink & May 2000 & $\begin{array}{l}\text { L. Tabada } \\
36896\end{array}$ \\
\hline WPS2353 & $\begin{array}{l}\text { The São Mateus-Jabaquara } \\
\text { Trolleybusway Concession in Brazil }\end{array}$ & $\begin{array}{l}\text { Jorge Rebelo } \\
\text { Pedro Machado }\end{array}$ & May 2000 & $\begin{array}{l}\text { S. Van Veldhuizen } \\
38722\end{array}$ \\
\hline WPS2354 & $\begin{array}{l}\text { When the Bureaucrats Move out of } \\
\text { Business: A Cost-Benefit } \\
\text { Assessment of Labor Retrenchment } \\
\text { in China }\end{array}$ & $\begin{array}{l}\text { YiChen } \\
\text { Ishac Diwan }\end{array}$ & May 2000 & $\begin{array}{l}\text { M. Yafi } \\
34649\end{array}$ \\
\hline WPS2355 & Greed and Grievance in Civil War & $\begin{array}{l}\text { Paul Collier } \\
\text { Anke Hoeffler }\end{array}$ & May 2000 & $\begin{array}{l}\text { A. Kitson-Walters } \\
33712\end{array}$ \\
\hline WPS2356 & $\begin{array}{l}\text { Bureaucratic Delegation and Political } \\
\text { Institutions: When Are Independent } \\
\text { Central Banks Irrelevant? }\end{array}$ & $\begin{array}{l}\text { Philip Keefer } \\
\text { David Stasavage }\end{array}$ & June 2000 & $\begin{array}{l}\text { P. Sintim-Aboagye } \\
37644\end{array}$ \\
\hline WPS2357 & $\begin{array}{l}\text { Evaluating Carbon Offsets from } \\
\text { Forestry and Energy Projects: } \\
\text { How Do They Compare? }\end{array}$ & Kenneth M. Chomitz & June 2000 & $\begin{array}{l}\text { J. Ancrum } \\
33512\end{array}$ \\
\hline WPS2358 & $\begin{array}{l}\text { Why Infrastructure Financing } \\
\text { Facilities Often Fall Short of Their } \\
\text { Objectives }\end{array}$ & $\begin{array}{l}\text { Daniela Klingebiel } \\
\text { Jeff Ruster }\end{array}$ & June 2000 & $\begin{array}{l}\text { M. Salehi } \\
37157\end{array}$ \\
\hline WPS2359 & $\begin{array}{l}\text { Reducing Carbon Dioxide Emissions } \\
\text { Through Joint Implementation of } \\
\text { Projects }\end{array}$ & Will Martin & June 2000 & $\begin{array}{l}\text { L. Tabada } \\
36896\end{array}$ \\
\hline WPS2360 & $\begin{array}{l}\text { Corruption and the Composition of } \\
\text { Foreign Direct Investment: } \\
\text { Firm-Level Evidence }\end{array}$ & $\begin{array}{l}\text { Beata K. Smarzynska } \\
\text { Shang-Jin Wei }\end{array}$ & June 2000 & $\begin{array}{l}\text { H. Sladovich } \\
37698\end{array}$ \\
\hline WPS2361 & $\begin{array}{l}\text { The Welfare Effects of Private Sector } \\
\text { Participation in Guinea's Urban Water } \\
\text { Supply }\end{array}$ & $\begin{array}{l}\text { George Clarke } \\
\text { Claude Ménard } \\
\text { Ana Maria Zuluaga }\end{array}$ & June 2000 & $\begin{array}{l}\text { H. Sladovich } \\
37698\end{array}$ \\
\hline WPS2362 & $\begin{array}{l}\text { A Transitory Regime: Water Supply } \\
\text { In Conakry, Guinea }\end{array}$ & $\begin{array}{l}\text { Claude Ménard } \\
\text { George Clarke }\end{array}$ & June 2000 & $\begin{array}{l}\text { H. Sladovich } \\
37698\end{array}$ \\
\hline WPS2363 & $\begin{array}{l}\text { Would Collective Action Clauses } \\
\text { Raise Borrowing Costs? An Update } \\
\text { and Additional Results }\end{array}$ & $\begin{array}{l}\text { Barry Eichengreen } \\
\text { Ashoka Mody }\end{array}$ & June 2000 & $\begin{array}{l}\text { S. Kpundeh } \\
39591\end{array}$ \\
\hline WPS2364 & $\begin{array}{l}\text { Perverse Effects of a Ratings- } \\
\text { Related Capital Adequacy System }\end{array}$ & Patrick Honohan & June 2000 & $\begin{array}{l}\text { A. Yaptenco } \\
38526\end{array}$ \\
\hline
\end{tabular}


Policy Research Working Paper Series

\begin{tabular}{|c|c|c|c|c|}
\hline & Title & Author & Date & $\begin{array}{l}\text { Contact } \\
\text { for paper }\end{array}$ \\
\hline WPS2365 & Leading Indicator Project: Lithuania & $\begin{array}{l}\text { Stephen S. Everhart } \\
\text { Robert Duval-Hernandez }\end{array}$ & June 2000 & $\begin{array}{l}\text { M. Geller } \\
85155\end{array}$ \\
\hline WPS2366 & $\begin{array}{l}\text { Fiscal Constraints, Collection Costs, } \\
\text { and Trade Policies }\end{array}$ & Keiko Kubota & June 2000 & $\begin{array}{l}\text { L. Tabada } \\
36896\end{array}$ \\
\hline
\end{tabular}

